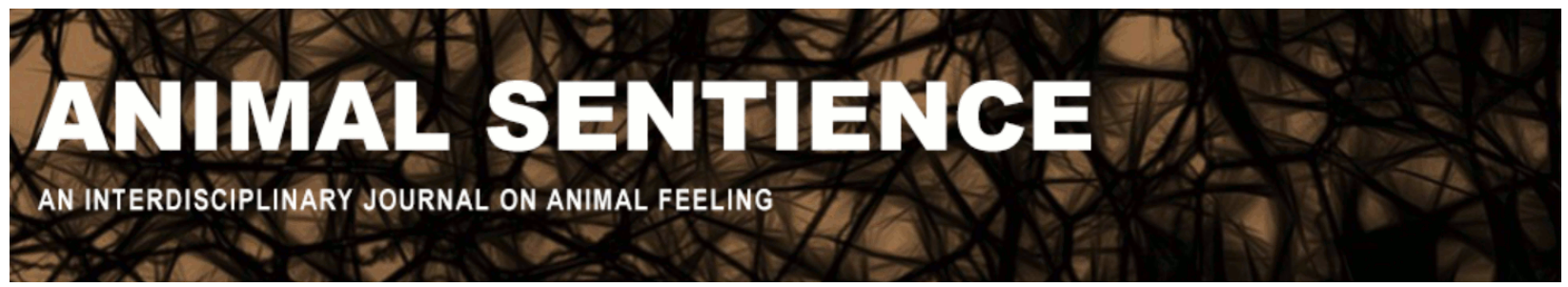

Clark, Stephen R. (2016) Slavery, welfare and the sixth extinction. Animal Sentience 7(13)

DOI: $10.51291 / 2377-7478.1103$

Date of submission: 2016-03-23

Date of acceptance: 2016-03-29

(c)

This article has appeared in the journal Animal

Sentience, a peer-reviewed journal on animal

cognition and feeling. It has been made open access,

free for all, by WellBeing International and deposited

in the WBI Studies Repository. For more information,

please contact

wbisr-info@wellbeingintl.org.

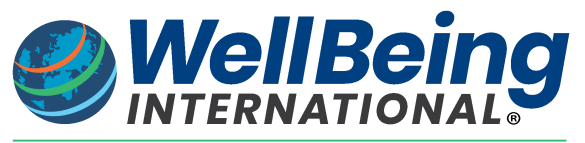

SOLUTIONS FOR PEOPLE, ANIMALS AND ENVIRONMENT 


\title{
Slavery, welfare and the sixth extinction
}

Commentary on $\mathrm{Ng}$ on Animal Suffering

\author{
Stephen R. L. Clark \\ Department of Philosophy \\ University of Liverpool
}

\begin{abstract}
Ng}^{\prime}$ s laudable concern for animal welfare would be welcome to any sensible slaveowner wishing to preserve his investment. What welfarism - for slave-owners and animal husbandmen - fails to call into question is whether we have the right to breed, hold captive and kill animals at all: If it matters, as the widely recognized slogan of 'Five Freedoms' suggests, that animals have the chance to live a 'normal' life, then more matters than keeping them 'happy' in subjection. Their lives - and also the lives of wild things - also deserve respect.
\end{abstract}

\begin{abstract}
Stephen R. L. Clark is Emeritus Professor of Philosophy, University of Liverpool, and Honorary Research Fellow, University of Bristol. His books include The Moral Status of Animals (1977), The Nature of the Beast (1982), How to

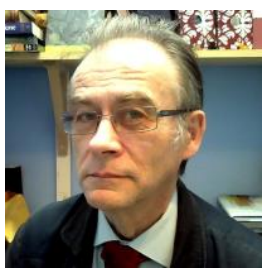
Think about the Earth (1993), Animals and Their Moral Standing (1997), Biology and Christian Ethics (2000), and Plotinus: Myth, Metaphor and Philosophical Practice (2016). http://pcwww.liv.ac.uk/ srlclark/srlc.htm
\end{abstract}

According to the Book of Proverbs (12.10) 'a righteous man regardeth the life of his beast: but the tender mercies of the wicked are cruel.' Such 'mercies' include debeaking chickens and castrating cattle, horses, and dogs to alleviate aggression. It is to the credit of $\mathrm{Ng}$ (2016) that he is concerned to relieve the suffering of domesticated (and some wild) animals by better means, and seeks to assure them some enjoyment - as long, that is, as we may continue to use them.

Slave-owners, of course, might have practised a similar care: slaves are valuable property (at least until old age, disease or injury diminishes their value) and sensible slave-owners take care of their health and even - in a way - their 'happiness.' Slaves may also rebel if pushed too far - and all slave-owning societies live in terror of the coming judgment. Domesticated animals are less likely to mount an organized rebellion (though individuals may sometimes snap), but sensible farmers still don't goad their bulls, even their sheep or cockerels, too far.

So 'welfarists' are the farmers' friends - pointing to better ways of managing the stock, and also (of course) alleviating some of the guilt that farmers may feel for what they do to the animals for whom they often feel affection. At least, we can be persuaded, these purposebred animals aren't unduly stressed, and some may have easier lives than their counterparts 'in the wild.' Unlike most human slaves, they don't understand their subjection, and have - it 
is argued - no strong wish to live their lives in freedom. Bad farmers, we keep being told those who do not care at all how 'their' animals feel or live - are likely also to be unprofitable farmers, precisely because they cannot distinguish their own complacent perspectives from the actual facts. Good husbandry - in every area of animal management depends on a good understanding of animals, and a clear sight of the costs of careless management, to the animals and to their owners.

None of this touches the fundamental problem, however: whether it can be right to enslave, imprison, mutilate and kill our cousins. Ng rightly rejects the hypothesis that 'animals' are no more than automata, as senseless as rocks or bushes, though more mobile. Nowadays any idea that 'animals' and 'humans' are so radically distinct can be maintained only by wilful rejection of the evidence of evolutionary history and shared bodily natures - shared DNA, shared viruses, shared anatomical structures. We are not just rather like animals: we are animals (Midgley 2002, p. xxxiii), and know what it's like to be so 'from within.'

But there is another presupposition still at work. Those who acknowledge that non-human animals are sentient, or even somewhat intelligent, may still believe - as slavers believed of slaves - that their lives and purposes are unimportant, that they don't deserve respect. $\mathrm{Ng}$ is concerned with animal feelings, the balance of suffering and enjoyment. It is enough that those in our care (?) are 'happy' (or happy enough), without wondering whether their lives have value. But consider the 'Five Freedoms' identified by the United Kingdom's Farm Animal Welfare Council (FAWC 2009) as the basis for assessing animal welfare. Four of these are uncontroversially 'welfarist': freedom from hunger and thirst; from discomfort; from pain, injury and disease; and freedom from fear and distress. The remaining freedom is more controversial, and more difficult to define: the freedom to express normal behaviour, allowed by 'providing sufficient space, proper facilities and appropriate company of the animal's own kind.'

The Council acknowledged that 'these definitions of good welfare do not place an explicit moral value on maintaining or extending the lifespan of a farm animal.... On the one hand it seems to many people to be commonsense that healthy animals, experiencing a good quality of life, lose out by having their lives prematurely terminated. On the other hand, farm animals clearly [sic] cannot imagine the future to anything like the extent that [adult?] humans can. In that sense, it is widely held that they lose very little by having their lives prematurely terminated so long, of course, as that is done humanely.'

Identical rationales are used in other contexts, and even by some owners of 'companion animals': it will almost always be cheaper to kill an animal than cure it, or otherwise alleviate its distress. How humane the killing may be is moot: the swiftest - and cheapest - method of killing surplus male chicks is to have them shredded, by 'Instantaneous Mechanical Destruction', in well-maintained, clean grinders (HSA 2005). But at least the acknowledged importance of 'normal lives,' lives well-lived according to their kind, goes beyond the mere assessment of their 'net happiness' ('enjoyment minus suffering'). However grudgingly, the Council acknowledged the 'commonsense' belief that animals may find their lives worth living if they are allowed to live them (that is, to find their places in their social worlds, and accomplish something of what they are formed to wish, even if it is only to stretch, bathe, breed, and play). Killing them is at least not a neutral act, and neither is enslaving them. 
One last comment: $\mathrm{Ng}$ is right that we know too little of wild animals to much improve their lives - our efforts, indeed, would probably make things worse. But we could begin by not using painful means to control or kill them, and not destroying their habitats. We may have fewer duties of care toward wild animals: we may still have duties not to harm them (see Clark 1997, pp. 16-30). It is not only domestic animals, after all, that we have damaged: we are living through what is justly called 'the Sixth Extinction' (Leakey \& Lewin 1996), destroying habitats and poisoning the seas. Until we can come to terms with the revelation that we are, in Leopold's phrase, 'all fellow voyagers in the odyssey of evolution' (Leopold 1966, p. 109), we shall continue to injure our cousins, and the hopes of our own survival.

\section{References}

Clark, S. R. L. (1997). Animals and their Moral Standing. London: Routledge.

FAWC. (2009). FAWC Report on Farm Animal Welfare in Great Britain: Past, Present and Future. London: Defra. https://www.gov.uk/government/publications/fawc-report-onfarm-animal-welfare-in-great-britain-past-present-and-future

HSA. (2005). Instantaneous Mechanical Destruction (Technical Note No. 9). Wheathampstead: Humane Slaughter Association. http://www.hsa.org.uk/.../technicalnotes/TN9-mechanical-destruction.pdf

Leakey, R. \& Lewin, R. (1996). The Sixth Extinction: Biodiversity and Its Survival. London: Weidenfeld \& Nicolson.

Leopold, A. (1966). Sand County Almanac. Oxford: Oxford University Press.

Midgley, M. (2002). Beast and Man. London: Routledge (1 $1^{\text {st }}$ published 1979).

$\mathrm{Ng}$, Y-K. (2016). How welfare biology and commonsense may help to reduce animal suffering. Animal Sentience 2016.007. 